\title{
Shape Memory Behavior of [111]-Oriented NiTi Single Crystals After Stress-Assisted Aging
}

\author{
Irfan Kaya $^{1} \cdot$ Hirobumi Tobe ${ }^{2} \cdot$ Haluk Ersin Karaca $^{2} \cdot$ Emre Acar $^{3} \cdot$ Yuriy Chumlyakov $^{4}$
}

Received: 2 November 2015/Revised: 15 December 2015/Published online: 26 February 2016

(C) The Chinese Society for Metals and Springer-Verlag Berlin Heidelberg 2016

\begin{abstract}
The shape memory behavior of [111]-oriented $\mathrm{Ni}_{51} \mathrm{Ti}_{49}$ (at.\%) single crystals was investigated after stressassisted aging at $500{ }^{\circ} \mathrm{C}$ for $1.5 \mathrm{~h}$ under a compressive stress of $-150 \mathrm{MPa}$. It was found that a single family of $\mathrm{Ni}_{4} \mathrm{Ti}_{3}$ precipitates with two crystallographically equivalent variants was formed after aging under compressive stress. Stressassisted aging resulted in tensile two-way shape memory effect strain of $1.56 \%$ under $-5 \mathrm{MPa}$. Thermal cycling under $-600 \mathrm{MPa}$ resulted in a transformation strain of $-2.15 \%$, while the subsequent thermal cycling under $-5 \mathrm{MPa}$ resulted in a tensile two-way shape memory effect strain of $2.2 \%$.
\end{abstract}

KEY WORDS: Shape memory alloy (SMA); Two-way shape memory effect; Aging treatment; Precipitation; Phase transformations

\section{Introduction}

Two-way shape memory effect (TWSME) represents the reversible and spontaneous shape change of materials with thermal cycling without the application of external stress. It is well known that TWSME property is not intrinsic to the shape memory alloys (SMAs), while it can be obtained by suitable thermomechanical training [1-6].

Available online at http://link.springer.com/journal/40195.

Irfan Kaya

irfan_kaya@anadolu.edu.tr

1 Department of Mechanical Engineering, Faculty of Engineering, Anadolu University, 26555 Eskisehir, Turkey

2 Department of Mechanical Engineering, University of Kentucky, Lexington, KY 40506, USA

3 Department of Aircraft Engineering, Erciyes University, 38039 Kayseri, Turkey

4 Siberian Physical-Technical Institute at Tomsk State University, Tomsk 634050, Russia
It is commonly accepted that the generation of anisotropic dislocation structures into the parent phase matrix during training creates anisotropic stress fields that help to the formation of preferentially oriented martensite variants. As a result of these oriented martensite variants, reversible shape changes occurred during stress-free thermal cycling [7, 8].

Ni-rich $\mathrm{Ni}_{4} \mathrm{Ti}_{3}$ precipitates play an essential role in twoway shape memory behavior of Ni-rich NiTi SMAs [9] where the internal stress fields around them could control formation and growth of the martensite variants [10-12]. In stress-free aging of NiTi alloys, four families of the precipitates are formed in austenite. On the other hand, aging under compressive stress along the [111] direction of NiTi single crystal leads to the creation of a single family of $\mathrm{Ni}_{4} \mathrm{Ti}_{3}$ precipitates [13-16]. The formation of $\mathrm{Ni}_{4} \mathrm{Ti}_{3}$ particles in NiTi single crystals allows us to control the strength, transformation temperatures and shape memory behavior of the crystal [17].

The stress-assisted aging induces TWSME through the selection of specific martensite variants by the formation of the stress fields around the aligned precipitates [18-22]. These aligned precipitates are perpendicular to the loading axis in the case of compression aging, while they have an angle of $20^{\circ}$ between the normal of the precipitate habit 
plane and the loading axis in the case of tension in [111] orientation [23]. TWSME strain $\left(\varepsilon_{\mathrm{tw}}\right)$ of $0.8 \%$ was observed for a [111]-oriented $\mathrm{Ni}_{51} \mathrm{Ti}_{49}$ single crystal alloy aged under a compressive stress [20].

Our previous work focused on the generation of TWSME in stress-free aged [111]-oriented $\mathrm{Ni}_{51} \mathrm{Ti}_{49}$ single crystals where the conditions required to observe compressive and tensile TWSMEs in NiTi were discussed. The compressive TWSME occurs when an alloy is plastically deformed in martensite, while the tensile TWSME appears after deformation of the austenite when the precipitates are present [24]. It has been revealed that the compressive and the tensile TWSME strains are produced by the formation of selected martensite variants due to the stress fields around the precipitates and dislocations. In this work, the TWSME response of [111]-oriented $\mathrm{Ni}_{51} \mathrm{Ti}_{49}$ single crystals after stress-assisted aging was systematically investigated in compression.

\section{Experimental}

The single crystal samples were grown by the Bridgman method in an inert gas atmosphere. The as-grown $\mathrm{Ni}_{51} \mathrm{Ti}_{49}$ single crystals were solution-annealed at $1000{ }^{\circ} \mathrm{C}$ for $2 \mathrm{~h}$ in argon-filled quartz ampoules and water quenched. Then, the crystals were aged at $500{ }^{\circ} \mathrm{C}$ for $1.5 \mathrm{~h}$ under an external compressive stress of $-150 \mathrm{MPa}$ applied along the [111] direction.

The microstructure after aging was investigated by transmission electron microscopy (TEM, JEOL 2010F). The thin foil specimens for TEM were prepared by a twin-jet electropolishing device in a solution consisting of (all vol\%) $20 \%$ sulfuric acid and $80 \%$ methanol at around $-15{ }^{\circ} \mathrm{C}$. TEM observations were carried out by TEM operated at an acceleration voltage of $200 \mathrm{kV}$. Compression specimens with the dimension of $4 \mathrm{~mm} \times 4 \mathrm{~mm} \times 8 \mathrm{~mm}$ were tested with $100 \mathrm{kN}$ MTS Landmark servo-hydraulic load frame with a strain rate of $10^{-4} \mathrm{~s}^{-1}$. The temperature of the sample was monitored by K-type thermocouples. An Omega CN8200 series temperature controller was used to govern a heating rate of $10{ }^{\circ} \mathrm{C} / \mathrm{min}$ and a cooling rate of $5{ }^{\circ} \mathrm{C} / \mathrm{min}$. TWSME tests are done under $-5 \mathrm{MPa}$ of compressive loading, which is required to keep the grips in contact with the samples to measure strain.

\section{Results and Discussion}

The transformation temperatures of stress-free aged $\left(500{ }^{\circ} \mathrm{C}, 1.5 \mathrm{~h}\right) \mathrm{Ni}_{51} \mathrm{Ti}_{49}$ single crystal alloy were determined as: $R_{\mathrm{S}}$ (R-phase start temperature) $=25^{\circ} \mathrm{C}, R_{\mathrm{f}}$
(R-phase finish temperature $)=16{ }^{\circ} \mathrm{C}, M_{\mathrm{s}}$ (martensite $\left(\mathrm{B} 19^{\prime}\right)$ start temperature $)=-7^{\circ} \mathrm{C}, M_{\mathrm{f}}\left(\right.$ martensite $\left(\mathrm{B} 19^{\prime}\right)$ finish temperature) $=-16{ }^{\circ} \mathrm{C}, A_{\mathrm{s}}$ (austenite start temperature) $=27{ }^{\circ} \mathrm{C}, \quad A_{\mathrm{f}} \quad$ (austenite finish temperature) $=33{ }^{\circ} \mathrm{C}[24]$.

Figure 1a shows the bright field micrograph and the corresponding selected area diffraction $(\mathrm{SAD})$ pattern obtained at room temperature for the $\mathrm{Ni}_{51} \mathrm{Ti}_{49}$ single crystal after stress-assisted aging. It should be noted that the matrix is $\mathrm{B} 19^{\prime}$ martensite, which is considered to be formed thermally during the electropolishing process at $-15{ }^{\circ} \mathrm{C}$. The SAD pattern was taken along the $[\overline{1} 10]_{\mathrm{Ni}_{4} \mathrm{Ti}_{3}}$ zone axis and some reflections from $\mathrm{Ni}_{4} \mathrm{Ti}_{3}$ precipitates were indexed. In the dark field image (Fig. 1b) taken by using the diffraction spot circled in the SAD pattern, a single family with two crystallographically equivalent variants of $\mathrm{Ni}_{4} \mathrm{Ti}_{3}$ precipitates was observed on the $(111)_{\mathrm{B} 2}$ plane perpendicular to the $[111]_{\mathrm{B} 2}$ compression direction. The $\mathrm{Ni}_{4} \mathrm{Ti}_{3}$ precipitates are $30-40 \mathrm{~nm}$ in thickness and $250-350 \mathrm{~nm}$ in length.

Figure 2 shows the thermal cycling under constant compressive stress responses of [111]-oriented $\mathrm{Ni}_{51} \mathrm{Ti}_{49}$ single crystal after stress-assisted aging. The specimen was loaded in austenite phase to selected stress levels and then cooled down below the martensite finish temperature $\left(M_{\mathrm{f}}\right)$ and heated above the austenite finish temperature $\left(A_{\mathrm{f}}\right)$. Multiple thermal cycling tests were performed at selected compressive stress levels ranging from $-5 \mathrm{MPa}$ to $-600 \mathrm{MPa}$.

It should be noted that the transformation temperatures increase with stress. Martensite start temperature $\left(M_{\mathrm{s}}\right)$ and $A_{\mathrm{f}}$ were $-7{ }^{\circ} \mathrm{C}$ and $31^{\circ} \mathrm{C}$ under $-25 \mathrm{MPa}$, while they were increased to $39{ }^{\circ} \mathrm{C}$ and $64{ }^{\circ} \mathrm{C}$ under $-600 \mathrm{MPa}$, respectively. During thermal cycling, two-stage (B2-RB19') transformation behavior was observed on cooling under low stress levels. At high stress levels, the austenite to R-phase transformation temperatures are almost stress independent, while austenite to martensite transformation temperatures are highly stress dependent, martensite transformation temperatures increase above R-phase transformation temperatures, and R-phase transformation disappears [25].

The thermal cycling under $-5 \mathrm{MPa}$ was accepted as the TWSME behavior where tensile TWSME strain $\left(\varepsilon_{\mathrm{tw}}\right)$ of $1.56 \%$ was observed. When the stress was increased to $-25 \mathrm{MPa}$, the tensile transformation strain was decreased to $0.54 \%$ and $-50 \mathrm{MPa}$ was needed to suppress the observation of tensile strain. For higher compressive stress levels, the compressive transformation strain increased with stress. While the transformation strain $\left(\varepsilon_{\mathrm{tr}}\right)$ was tensile $(1.56 \%)$ under $-5 \mathrm{MPa}$, it was compressive $(-2.15 \%)$ under $-600 \mathrm{MPa}$.

The irrecoverable strain $\left(\varepsilon_{\text {irr }}\right)$ was calculated by taking the difference between the strain values of cooling and heating 

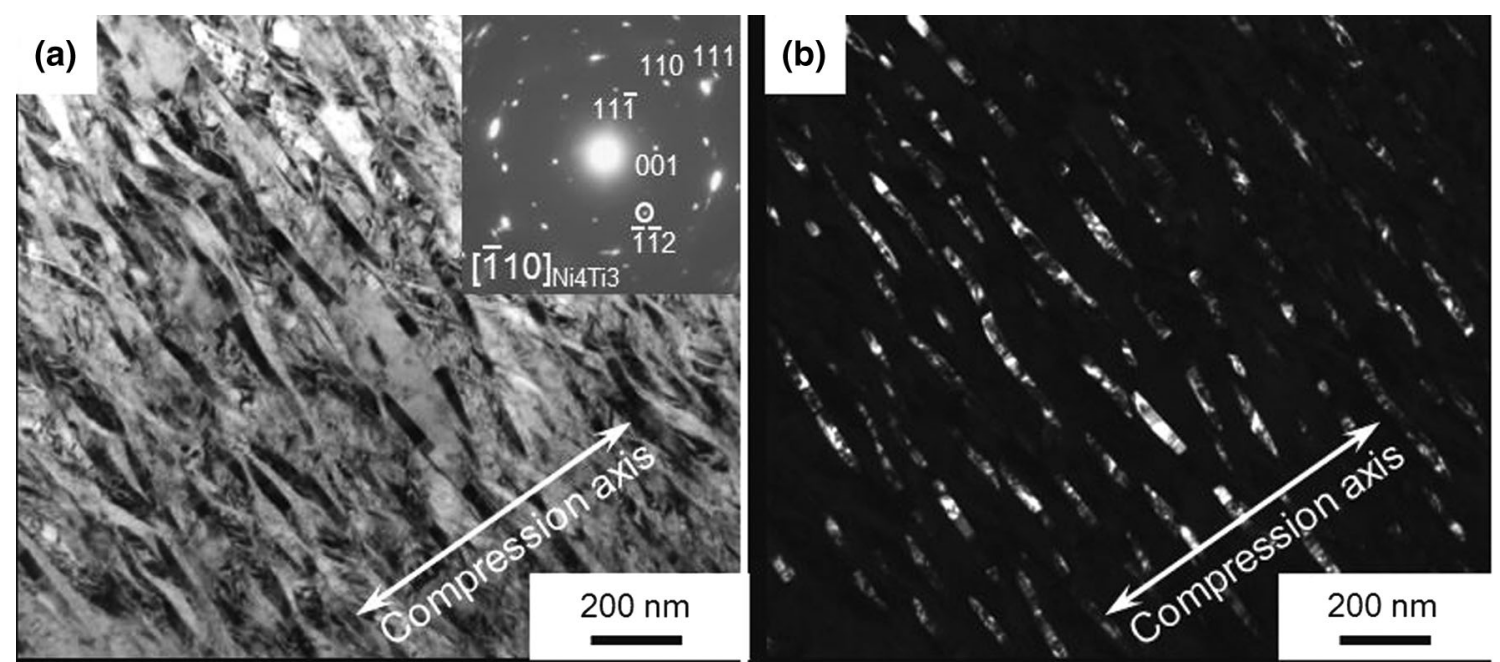

Fig. 1 a Bright field image and the corresponding SAD pattern of the $\mathrm{Ni}_{51} \mathrm{Ti}_{49}$ single crystal aged at $500{ }^{\circ} \mathrm{C}$ for $1.5 \mathrm{~h}$ under $-150 \mathrm{MPa}$; b Dark field image taken using the $\overline{1} 12_{\mathrm{Ni}_{4} \mathrm{Ti}_{3}}$ reflection circled in the SAD pattern in $\mathbf{a}$
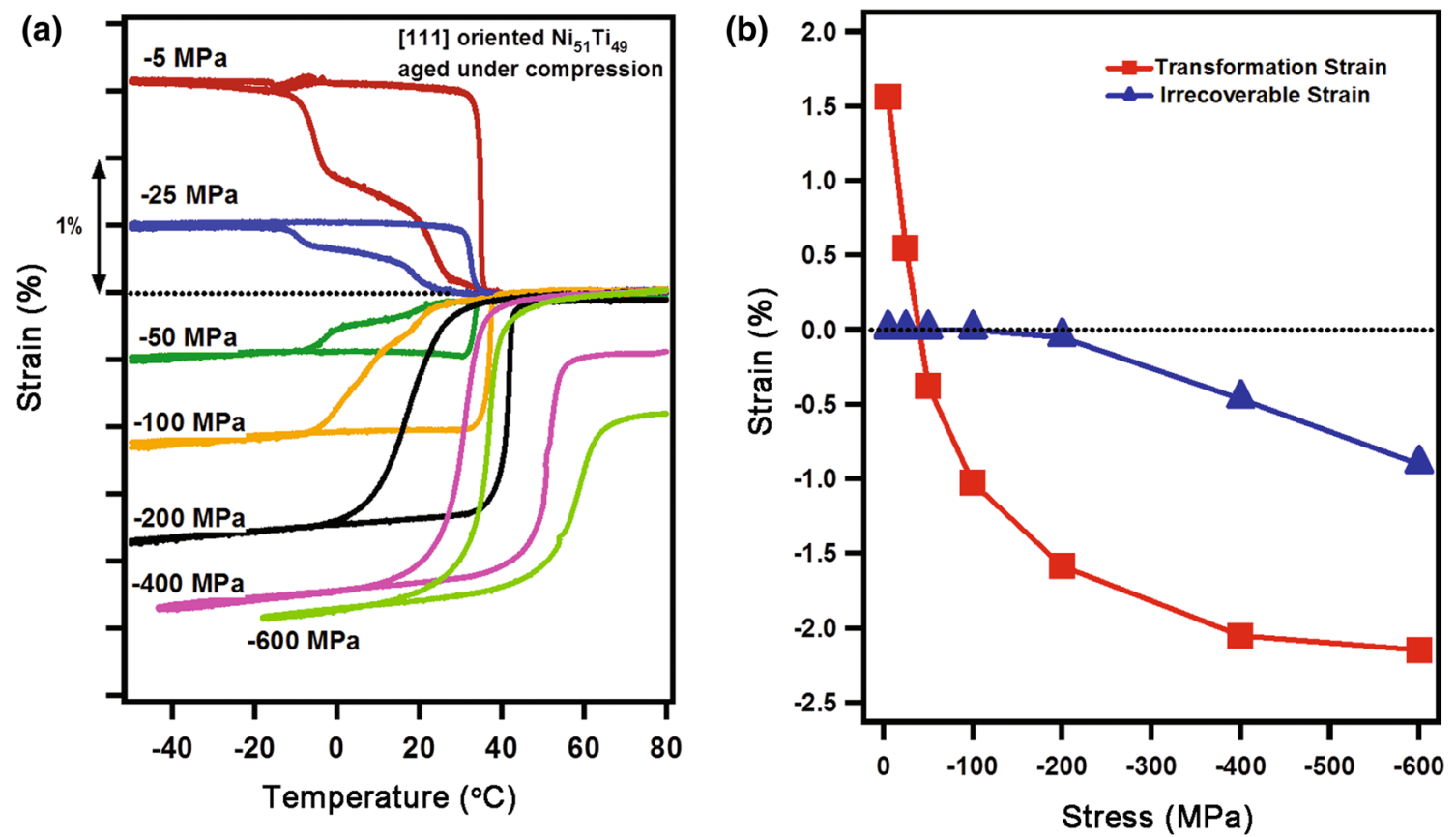

Fig. 2 a Thermal cycling under selected constant compressive stresses, $\mathbf{b}$ transformation and irrecoverable strains as a function of applied stress for the [111]-oriented $\mathrm{Ni}_{51} \mathrm{Ti}_{49}$ single crystals aged at $500{ }^{\circ} \mathrm{C}$ for $1.5 \mathrm{~h}$ under $-150 \mathrm{MPa}$

curves at $70{ }^{\circ} \mathrm{C}$. The irrecoverable strain was $-0.05 \%,-0.46 \%$ and $-0.9 \%$ under $-200,-400$ and $-600 \mathrm{MPa}$, respectively.

Figure 3 a shows the thermal cycling responses of stressfree and stress-assisted aged $\mathrm{Ni}_{51} \mathrm{Ti}_{49}$ single crystal alloys under -5 MPa. The initial TWSME strain after stress-free aging was $-0.4 \%$. On the other hand, when the sample was aged under stress, the precipitates were aligned, and tensile TWSME strain of $1.56 \%$ was observed.

Figure $3 \mathrm{~b}$, c shows the thermal cycling responses under $-600 \mathrm{MPa}$ and the subsequent TWSME of aged [111]- oriented $\mathrm{Ni}_{51} \mathrm{Ti}_{49}$ single crystals, respectively. The tensile TWSME strain of $1.4 \%$ was obtained after thermal cycling under $-600 \mathrm{MPa}$ in the stress-free aged sample. The tensile TWSME strain in the stress-assisted aged sample was increased after thermal cycling under $-600 \mathrm{MPa}$, where a large tensile TWSME strain of $2.2 \%$ was obtained. It should be noted that while the transformation strain was $-2.15 \%$ at $-600 \mathrm{MPa}$, the subsequent TWSME strain was $2.2 \%$ tensile for the stress-assisted aged sample. 


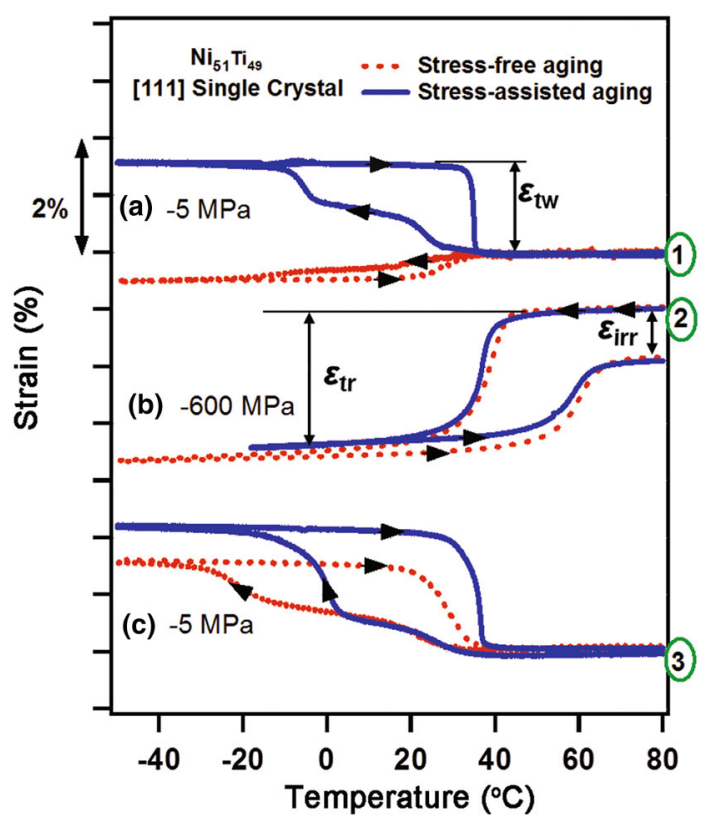

Fig. 3 a TWSME, b thermal cycling under $-600 \mathrm{MPa}$ and c TWSME after thermal cycling under $-600 \mathrm{MPa}$ of stress-free and stress-assisted aged [111]-oriented $\mathrm{Ni}_{51} \mathrm{Ti}_{49}$ single crystals

The effects of aging and external stress on the formation of $\mathrm{Ni}_{4} \mathrm{Ti}_{3}$ precipitates were schematically illustrated in Fig. 4. Stress-free aging produces four families of $\mathrm{Ni}_{4} \mathrm{Ti}_{3}$ precipitates on the four $\{111\}_{\mathrm{B} 2}$ habit planes, i.e. $(111)_{\mathrm{B} 2}$, $(\overline{1} 11)_{\mathrm{B} 2},(1 \overline{1} 1)_{\mathrm{B} 2}$ and $(11 \overline{1})_{\mathrm{B} 2}$ planes (Fig. 4a). Compressive stress applied along the $[111]_{\mathrm{B} 2}$ direction during aging results in one family of $\mathrm{Ni}_{4} \mathrm{Ti}_{3}$ precipitates on the $(111)_{\mathrm{B} 2}$ plane (Fig. 4b) because $\mathrm{Ni}_{4} \mathrm{Ti}_{3}$ precipitates shrink in the $[111]_{\mathrm{Ni}_{4} \mathrm{Ti}_{3}}\left(/ /<111>_{\mathrm{B} 2}\right)$ direction on their formation from the austenite matrix [26, 27].

The single family of $\mathrm{Ni}_{4} \mathrm{Ti}_{3}$ precipitates creates tensile stress in the matrix along the $[111]_{\mathrm{B} 2}\left(/ /[111]_{\mathrm{Ni}_{4} \mathrm{Ti}_{3}}\right)$ direction and selects specific R-phase variants. Considering the lattice correspondence between B2 austenite and R-phase [28], $[111]_{R},[\overline{1} 11]_{R},[1 \overline{1} 1]_{R}$ and $[11 \overline{1}]_{R}$ directions of $\mathrm{R}$-phase are derived from the $[111]_{\mathrm{B} 2}$ direction of the austenite and the $[111]_{\mathrm{R}}$ direction is the most expansible one. Therefore, the tensile stress along the $[111]_{\mathrm{B} 2}$ direction in the austenite matrix created by $\mathrm{Ni}_{4} \mathrm{Ti}_{3}$ precipitates facilitates the formation of $[111]_{\mathrm{R}} / /[111]_{\mathrm{B} 2} \mathrm{R}$-phase variants. Figure $4 \mathrm{c}$ shows the schematic for tensile TWSME creation due to the R-phase transformation after compressive stress-assisted aging. Since the specimen has only one family of $\mathrm{Ni}_{4} \mathrm{Ti}_{3}$ precipitates, the $[111]_{\mathrm{R}} / /[111]_{\mathrm{B} 2} \mathrm{R}$-phase variants are selected and they made the specimen elongate along the $[111]_{\mathrm{B} 2}$ compression direction, resulting in tensile TWSME.

On the other hand, $[110]_{\mathrm{B} 19^{\prime}},[\overline{1} \overline{1} 0]_{\mathrm{B} 19^{\prime}},[10 \overline{1}]_{\mathrm{B} 19^{\prime}}$ and $[\overline{1} 0 \overline{1}]_{\mathrm{B} 19^{\prime}}$ directions are derived from the $[111]_{\mathrm{B} 2}$ direction (a)

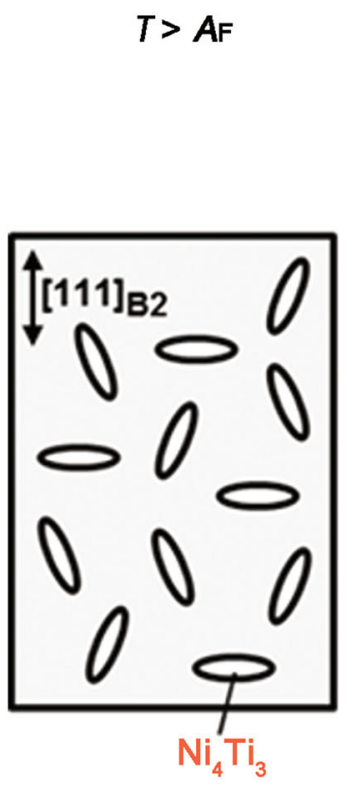

(b)

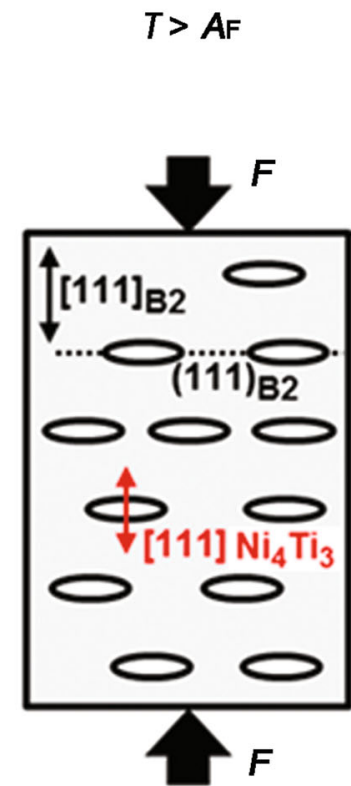

(c)

(d)

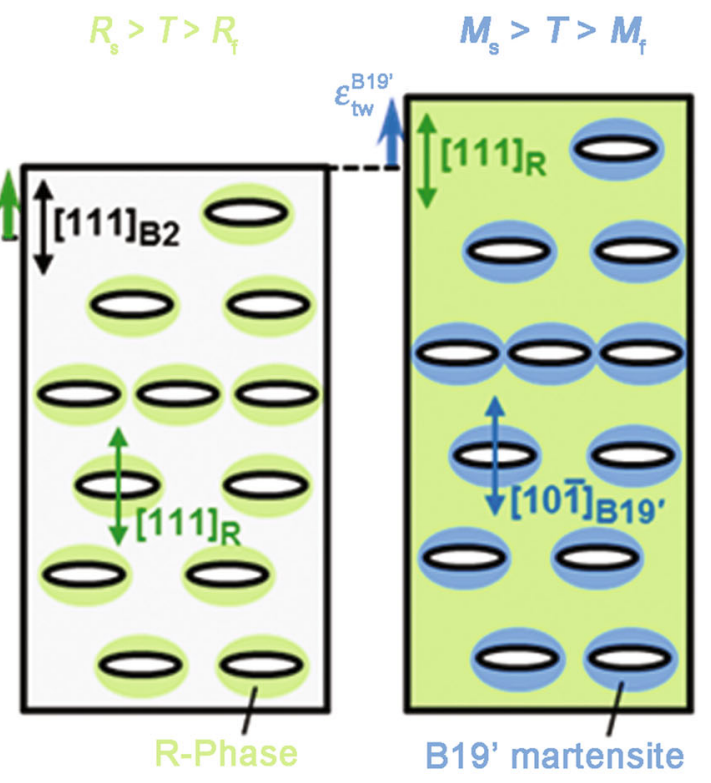

Fig. 4 Schematic illustrations of the formation of $\mathrm{Ni}_{4} \mathrm{Ti}_{3}$ precipitates in $\mathrm{NiTi}$ SMAs after aging in stress-free condition a and under compressive stress $\mathbf{b}$. Schematic illustrations for the generation of tensile TWSME due to R-phase transformation $\mathbf{c}$ and B19' martensite transformation $\mathbf{d}$ after stress-assisted aging 
in the $\mathrm{B} 2-\mathrm{B} 19^{\prime}$ transformation and the $[10 \overline{1}]_{\mathrm{B} 19^{\prime}}$ direction is the most expansible one [24]. Therefore, $[10 \overline{1}]_{\mathrm{B} 19^{\prime} / /[111]_{\mathrm{B} 2}}$ martensite variants are selected during the subsequent B19' martensite transformation (Fig. 4d), which results in further increase in tensile TWSME strain and two-stage behavior, as shown in Fig. 2.

The tensile TWSME strain of the sample after compressive stress-assisted aging was increased after thermal cycling under $-600 \mathrm{MPa}$ (Fig. 3c). It was previously reported in stress-free aged specimens that the dislocations introduced during thermal cycling under compressive stress accumulate around $\mathrm{Ni}_{4} \mathrm{Ti}_{3}$ precipitates and created back stresses along the external compression direction [24]. The back stress resulted in further selection of the $[10 \overline{1}]_{\mathrm{B} 19^{\prime} / /}$ $[111]_{\mathrm{B} 2}$ variants and produced increased two-stage tensile TWSME (Fig. 3c). Thus, the increase in the tensile TWSME strain in the stress-assisted aged specimen can be attributed to the creation of back stresses by the dislocations around $\mathrm{Ni}_{4} \mathrm{Ti}_{3}$ precipitates that facilitates the selec-

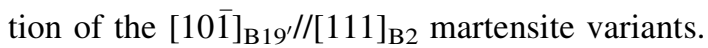

After thermal cycling under $-600 \mathrm{MPa}$, the sample that was aged under stress exhibited tensile TWSME strain of $2.2 \%$, which was as large as the maximum compressive SME strain of $-2.15 \%$ obtained by the thermal cycling under constant stress tests (Fig. 2). It can be concluded that the combination of stress-assisted aging and back stress creation by dislocation formation are an effective method to obtain large tensile TWSME strains in Ni-rich NiTi SMAs.

\section{Conclusion}

The effect of stress-assisted aging on the TWSME behavior of $\mathrm{Ni}_{51} \mathrm{Ti}_{49}$ single crystal along the [111] orientation was investigated. Single family of $\mathrm{Ni}_{4} \mathrm{Ti}_{3}$ particles was formed after aging at $500^{\circ} \mathrm{C}$ under an applied compressive stress of $-150 \mathrm{MPa}$ along the [111] direction. The formed $\mathrm{Ni}_{4} \mathrm{Ti}_{3}$ precipitates were $30-40 \mathrm{~nm}$ in thickness and $250-350 \mathrm{~nm}$ in length. Since the single family of $\mathrm{Ni}_{4} \mathrm{Ti}_{3}$ precipitates was formed, $[111]_{\mathrm{R}}$ and $[10 \overline{1}]_{\mathrm{B} 19^{\prime}}$ variants were formed due to the aligned stress fields along the precipitates to elongate the specimen along the $[111]_{\mathrm{B} 2}$ compression direction and resulted in two-stage tensile TWSME during cooling. The maximum TWSME strain was observed to be tensile of $2.2 \%$ after thermal cycling training under $-600 \mathrm{MPa}$ with $-2.15 \%$ transformation strain. The increase in TWSME after thermal cycling under $-600 \mathrm{MPa}$ is attributed to the back stress creation by the dislocations around $\mathrm{Ni}_{4} \mathrm{Ti}_{3}$ precipitates.
Acknowledgments This work was supported in part by the NASA Fundamental Aeronautics Program, Supersonics Project and the NASA EPSCOR program (Grant No. NNX11AQ31A), and RFBR Project (Grant No. 10-03-0154-a).

\section{References}

[1] J. Perkins, R.O. Sponholz, Metall. Trans. A 15, 313 (1984)

[2] L. Contardo, G. Guénin, Acta Metall. Mater. 38, 1267 (1990)

[3] Y. Liu, P.G. McCormick, Acta Metall. Mater. 38, 1321 (1990)

[4] R. Stalmans, J. Van Humbeeck, L. Delaey, Acta Metall. Mater. 40, 501 (1992)

[5] K. Wada, Y. Liu, Mater. Sci. Eng. A 481-482, 166 (2008)

[6] Z. Wang, X. Zu, X. Feng, J. Dai, Mater. Lett. 54, 55 (2002)

[7] K. Enami, A. Nagasawa, S. Nenno, Scr. Metall. 9, 941 (1975)

[8] Z. Wang, X. Zu, J. Dai, P. Fu, X. Feng, Mater. Lett. 57, 1501 (2003)

[9] M. Nishida, C.M. Wayman, R. Kainuma, T. Honma, Scr. Metall. 20, 899 (1986)

[10] M.S. Shakeri, J. Khalil-Allafi, V. Abbasi-Chianeh, A. Ghabchi, J. Alloys Compd. 485, 320 (2009)

[11] K. Wada, Y. Liu, J. Alloys Compd. 449, 125 (2008)

[12] E. Cingolani, M. Ahlers, Mater. Sci. Eng. A 273-275, 595 (1999)

[13] J. Michutta, M. Carroll, A. Yawny, C. Somsen, K. Neuking, G. Eggeler, Mater. Sci. Eng. A 378, 152 (2004)

[14] M. Nishida, T. Honma, Scr. Metall. 18, 1293 (1984)

[15] Y.I. Chumlyakov, E.Y. Panchenko, V. Aksenov, I. Kireeva, M. Kuksa, I. Karaman, H. Sehitoglu, in Journal de Physique IV (Proceedings) (EDP Sciences, 2004), pp. 21-28

[16] J.F. Li, Z.Q. Zheng, X.W. Li, Z.W. Peng, Mater. Des. 30, 314 (2009)

[17] Y.I. Chumlyakov, I. Kireeva, E.Y. Panchenko, V. Aksenov, V. Kirillov, A. Ovsyannikov, E. Zakharova, H. Sehitogly, Russ. Phys. J. 46, 811 (2003)

[18] A. Gyobu, Y. Kawamura, H. Horikawa, T. Saburi, Mater. Sci. Eng. A 273, 749 (1999)

[19] T. Fukuda, A. Deguchi, T. Kakeshita, T. Saburi, Mater. Trans. JIM 38, 514 (1997)

[20] T. Fukuda, M. Takahata, T. Kakeshita, T. Saburi, Mater. Trans. 42, 323 (2001)

[21] C.-Y. Chang, D. Vokoun, C.-T. Hu, Metall. Mater. Trans. A 32, 1629 (2001)

[22] J.F. Li, Z.Q. Zheng, X.W. Li, S.C. Li, Mater. Sci. Eng. A 523, 207 (2009)

[23] S.C. Weighardt, H.J. Maier, Y.I. Chumlyakov, J. Alloys Compd. 577, S219 (2013)

[24] I. Kaya, H. Tobe, H. Karaca, M. Nagasako, R. Kainuma, Y. Chumlyakov, Mater. Sci. Eng. A 639, 42 (2015)

[25] H. Karaca, I. Kaya, H. Tobe, B. Basaran, M. Nagasako, R. Kainuma, Y. Chumlyakov, Mater. Sci. Eng. A 580, 66 (2013)

[26] T. Tadaki, Y. Nakata, K.I. Shimizu, K. Otsuka, Trans. Jpn. Inst. Methods 27, 731 (1986)

[27] R. Kainuma, M. Matsumoto, T. Honma, in Proceedings of the International Conference on Martensitic Transformations (ICOMAT-86, 1986), pp. 717-722

[28] S. Miyazaki, C. Wayman, Acta Metall. 36, 181 (1988) 